\title{
Genomic Detection of Schmallenberg Virus, Israel
}

\author{
Adi Behar, Omer Izhaki, Asael Rot, Tzvika Benor, Mario Yankilevich, \\ Monica Leszkowicz-Mazuz, Jacob Brenner
}

We discuss genomic detection of Schmallenberg virus in both Culicoides midges and affected ruminants during June 2018-December 2019, demonstrating its circulation in Israel. This region is a geographic bridge between 3 continents and may serve as an epidemiologic bridge for potential Schmallenberg virus spread into Asia.

S imbu serogroup viruses form one of the largest serogroups in the genus Orthobunyavirus of the family Peribunyaviridae, comprising $\geq 25$ antigenically different, but serologically related, negativesense single-stranded RNA viruses. These viruses are transmitted mainly by Culicoides biting midges; they persist in the environment by cycling between infected mammalian hosts and Culicoides vectors. Notable examples from the Simbu serogroup are Akabane virus (AKAV), Aino virus, Schmallenberg virus (SBV), Sathuperi virus (SATV), Shamonda virus (SHAV), Peaton virus (PEAV), and Shuni virus (SHUV, which is also suspected of infecting humans.). These viruses are known to cross the placenta of ruminants to the developing fetus, causing abortion, stillbirth, and neonatal malformations that are seen only at birth. The congenital malformations are termed arthrogryposishydranencephaly syndrome. Given that the clinical signs can be observed only months after viremia has occurred, field and laboratory practitioners are at a huge disadvantage when facing epidemics caused by these viruses (1-7).

Until recently, the most studied viruses of the Simbu serogroup were AKAV and Aino virus, both known to be present in Israel (1,3). In 2011, a new Simbu virus emerged in Europe and was named Schmallenberg virus (SBV) (8). Studies suggested that $\mathrm{SBV}$ is a reassortant virus, deriving the medium (M)

Author affiliations: Kimron Veterinary Institute, Beit Dagan, Israel (A. Behar, O. Izhaki, A. Rot, M. Leszkowicz-Mazuz, J. Brenner); Veterinary Field Services, Beit Dagan, Israel (T. Benor, M. Yankilevich)

DOI: https://doi.org/10.3201/eid2708.203705
RNA segment from SATV and the small (S) and large (L) RNA segments from SHAV, probably as a result of co-infection of these viruses in either Culicoides vectors or the ruminant hosts $(1,9,10)$.

Once SBV emerged in Europe, it was clear to our team in Israel that this virus was either already present in Israel or would be introduced in the future. After AKAV and SHUV outbreaks $(3,11)$ and virus neutralization test assays showing the additional presence of SATV, SHAV, and PEAV in Israel (12), a systematic monitoring system for arboviruses was established in 2015. Serum samples and vectors are collected every month from 13 selected dairy farms representing different geographic regions in Israel (Figure). Specific PEAV, SHUV, and SATV RNA fragments were also detected by nested quantitative PCR (qPCR) from different Culicoides species during 2015-2017 (13). Furthermore, in 2017, RNA fragments of a specific PEAV were detected in the cerebrospinal fluid (CSF) and testicles of a malformed calf exhibiting hydranencephaly (14). SBV was not found in all the studies conducted during 2011-2017, nor was it detected passively in Israel (3,11-14). We report the detection of SBV RNA in Israel in both vectors and affected ruminants.

\section{The Study}

During June 2018-December 2019, we trapped 13 pools of Culicoides imicola, 8 pools of C. oxystoma, 5 pools of $C$. puncticollis, and 5 pools of $C$. newsteadii midges (each pool containing 50 midges) around livestock farms, and we tested CSF from 3 malformed 1-day-old lambs (born on July 3, 2019) and 1 malformed 11-day-old calf (born on November 1, 2019) (Figure; Appendix, https://wwwnc.cdc. gov/EID/article/27/8/20-3705-App1.pdf). We extracted RNA from Culicoides homogenates and CSF using Maxwell 16 Viral Total Nucleic Acid Purification Kit (Promega, https:/ / www.promega.com) according to the manufacturer's instructions. We used total viral nucleic acids $(0.4 \mu \mathrm{g})$ for cDNA synthesis 


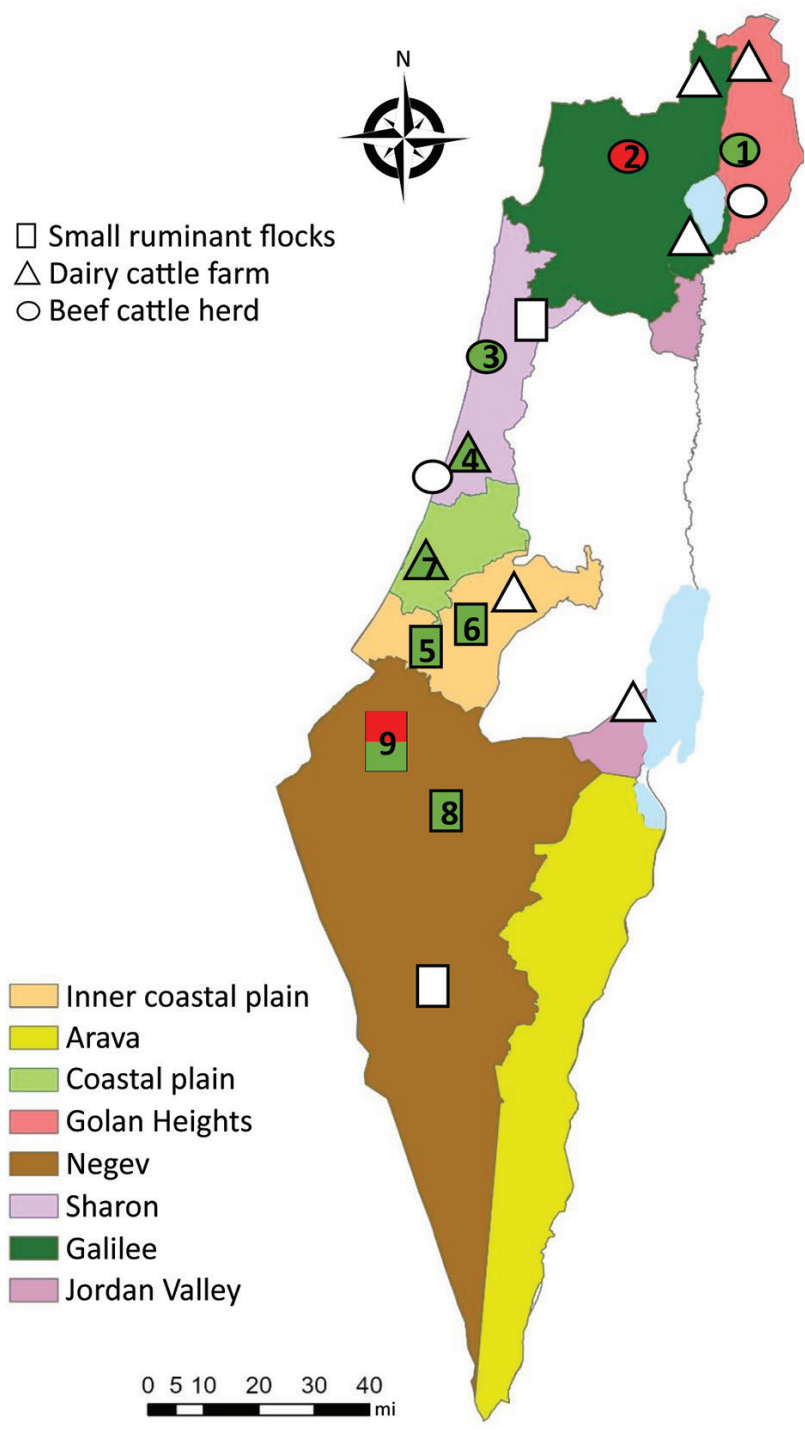

Figure. Locations and types of farms sampled in study of Schmallenberg virus (SBV), Israel. Farm numbers match those listed in Table 2. Green, farms from which SBV-positive Culicoides pools were collected; red, farms on which SBV-positive malformed progeny were detected. by UltraScript Reverse transcription (PCR Biosystems, https://www.promega.com) according to the manufacturer's instructions. We performed reverse transcription (RT) nested qPCR targeting the L RNA segment of Simbu serogroup viruses according to Behar et al. (13). We further subjected samples suspected of being Simbu serogroup positive to RT-nested and seminested PCRs performed using $S, M$, and L segment-specific primer sets (Table 1; Appendix).

Of the 31 species-specific pools from the $4 \mathrm{Cu}$ licoides midge species that are known or suspected to be vectors of Simbu serogroup viruses (i.e., $C$. imicola, C. oxystoma, C. puncticollis, C. newsteadii) $(2,12,15)$, we found that 11 contained RNA of Simbu serogroup viruses in 2018 and 2019 (35\% of the total pools tested) (Table 2; Figure; Appendix Table). We identified partial nucleotide sequences of the $\mathrm{S}$ (370/830 bp) and L (370/6,882 bp) segments. Phylogenetic analysis of the samples showed that all positive samples were virtually identical to SBV (GenBank accession nos. MT816474-82, MT816485-95) (Appendix Figure, panels A, C). These samples were collected from several different geographic regions in Israel (Table 2, lines 1 and 3-12 in the Samples column; Figure; Appendix Table). In addition, we detected SBV RNA-specific fragments of the S $(370 / 850$ bp), $\mathrm{M}(430 / 4,373 \mathrm{bp})$, and L segments $(370 / 6,882$ bp) in a CSF sample from a malformed lamb born in July 2019 on a farm in southern Israel (Negev desert) and a malformed calf born in November 2019 on a farm in northern Israel (Galilee) (GenBank accession nos. MT816472, MT816473, MT816483, MT816484, MT816496, MT816497) (Table 2, lines 2 and 13 in the Samples column; Appendix Figure).

In general, the most susceptible period for induction of congenital malformations by Simbu serogroup viruses is 65-70 days of gestation in lambs and 150 days of gestation in calves $(1,7)$. Thus, SBV detection

\begin{tabular}{|c|c|c|c|c|}
\hline Segment & External primer sequence, $5^{\prime} \rightarrow 3^{\prime}$ & Internal primer sequence, $5^{\prime} \rightarrow 3^{\prime}$ & $\begin{array}{c}\text { Expected } \\
\text { product size, bp }\end{array}$ & Reference \\
\hline S & $\begin{array}{l}\text { AKAI206F: CAC AAC CAA GTG TCG } \\
\text { ATC TTA } \\
\text { SimbuS637: GAG AAT CCA GAT TTA } \\
\text { GCC CA }\end{array}$ & $\begin{array}{c}\text { S_nestF: TGG TTA ATA ACC ATT TTC } \\
\text { CCC A } \\
\text { S_nestR: GTC ATC CAY TST TCW GCA } \\
\text { GTC A }\end{array}$ & 370 & $\begin{array}{l}\text { External: (4); } \\
\text { internal: this study }\end{array}$ \\
\hline M & $\begin{array}{l}\text { 924F: CCG AAA ACA AGG AAA TTG TG } \\
\text { 2331R: GGT TCA AAC ATC TCT AGG C }\end{array}$ & $\begin{array}{l}\text { 1899F: TAT AGT CCC TGG ATT AGG } \\
\text { TC } \\
\text { 2331R: GGT TCA AAC ATC TCT AGG C }\end{array}$ & 430 & $\begin{array}{l}\text { Forward primers: } \\
\text { (8); reverse } \\
\text { primers: this study }\end{array}$ \\
\hline L & $\begin{array}{c}\text { SNL_F: GCA AAC CCA GAA TTT GYW } \\
\text { GA } \\
\text { SNL_R: ATT SCC TTG NAR CCA RTT } \\
\text { YC }\end{array}$ & $\begin{array}{c}\text { panOBV-L-2959 F: TTG GAG ART ATG } \\
\text { ARG CTA ARA TGT G } \\
\text { panOBV-L-3274R: TGA GCA CTC CAT } \\
\text { TTN GAC ATR TC }\end{array}$ & 370 & $\begin{array}{l}\text { External: this } \\
\text { study; internal: } \\
(6)\end{array}$ \\
\hline
\end{tabular}


Table 2. Samples that tested positive for Schmallenberg virus by reverse transcription nested PCR, Israel ${ }^{*}$

\begin{tabular}{|c|c|c|c|}
\hline Geographic region & Sample source & Collection date & Infected farm type (farm no.) \\
\hline Golan Heights (latitude 34.1 ) & Culicoides oxystoma midge & 2018 Sep & Beef cattle (1) \\
\hline Galilee (latitude 32.7-33.5) & Malformed calf & 2019 Nov & Beef cattle $(2) \dagger$ \\
\hline \multirow[t]{4}{*}{ Sharon plain (latitude 32.2 ) } & C. imicola midge & 2018 Jun & Beef cattle $(3) \S$ \\
\hline & C. puncticollis midge & 2018 Jun & Beef cattle $(3) \S$ \\
\hline & C. newsteadii midge & 2018 Jun & Beef cattle $(3) \S$ \\
\hline & C. imicola midge & $2018 \mathrm{Jul}$ & Dairy cattle (4) \\
\hline \multirow[t]{3}{*}{ Interior plain (latitude 31.89) } & C. imicola midgef & 2018 Nov & Small ruminant farm (5)†§ \\
\hline & C. imicola midge & 2018 Nov & Small ruminant farm $(5) \dagger \S$ \\
\hline & C. imicola midge $\ddagger$ & $2019 \mathrm{Dec}$ & Small ruminant farm $(6) \S$ \\
\hline Coastal plain (latitude 31.89) & C. oxystoma midge & 2018 Jun & Dairy cattle $(7)$ \\
\hline \multirow[t]{3}{*}{ Negev desert (latitude 29.7-30.714) } & C. oxystoma midge & 2018 Nov & Small ruminant farm (8)§ \\
\hline & C. puncticollis midge & 2019 Jul & Small ruminant farm $(9)+\pi$ \\
\hline & Malformed lamb & 2019 Jul & Small ruminant farm (9)十帀 \\
\hline South Jordan Valley (latitude 31.56) & NA & NA & NA \\
\hline \multicolumn{4}{|c|}{$\begin{array}{l}\text { "NA, not applicable. } \\
\text { †Farms on which dams and ewes gave birth to stillborn and malformed neonates. } \\
\text { †Samples were confirmed positive at Friedrich Loeffler Institute, Greifswald, Germany. } \\
\text { \$Farms expecting a rate of } 80 \%-85 \% \text { prolificacy, but during calving season showed only } 50 \%-65 \% \text { prolificacy. } \\
\text { ISheep farm from which both insects and malformed lambs were sampled. }\end{array}$} \\
\hline
\end{tabular}

in the respective ruminants fits with viral infection in March-April 2019, suggesting exposure to SBV in Israel in early spring 2019. Nevertheless, reports on severe decline in progeny prolificacy, stillbirths, and malformed lambs were reported by farmers to the Veterinary Field Services from autumn 2018 through December 2019 (Table 2). The detection of SBV in $\mathrm{Cu}$ licoides pools collected from several of those farms (Table 2, lines 3-5, 7-9, and 11-12 in the Sample column; Figure; Appendix Table) suggests that SBV might have been clinically affecting ruminants in Israel as early as June 2018 .

\section{Conclusions}

Our results demonstrate the circulation of SBV outside Europe. Future studies are needed to determine the seroprevalence of SBV in the Middle East, because this information is essential for understanding the risk of SBV spread into countries in Asia. Because SATV is found in the Middle East $(12,13)$, virus neutralization tests will probably not be able to properly distinguish between antibodies against SBV and those against SATV. Therefore, developing a competitive ELISA system using SBV-specific antibodies is crucial. Finally, the presence of both SATV and SBV in Israel provides a unique opportunity for comparative studies on possible cross-protection of SBV commercial vaccines between these viruses.

\section{Acknowledgments}

We thank Raid Almhdi and Rachel Gabrieli for assisting with the insect collections; Shmuel Zamir, Ricardo Wolkomirsky, Lior Zamir, and Faris Hmd for assisting with sample collections; and Martin Beer and Kristin Wernike for external validation.

\section{About the Author}

Dr. Behar is a researcher working in the parasitology division of Kimron Veterinary Institute in Beit Dagan, Israel. She established and is running the arbovirus systematic monitoring system of the Israeli Veterinary Services. Her research interests include the interactions among bloodsucking insects, their microbiota, and the pathogens that they transmit.

\section{References}

1. De Regge N. Akabane, Aino and Schmallenberg virus where do we stand and what do we know about the role of domestic ruminant hosts and Culicoides vectors in virus transmission and overwintering? Curr Opin Virol. 2017;27:15-30. https:// doi.org/10.1016/j.coviro.2017.10.004

2. Sick F, Beer M, Kampen H, Wernike K. Culicoides biting midges - underestimated vectors for arboviruses of public health and veterinary importance. Viruses. 2019;11:376-94. https:/ / doi.org/10.3390/v11040376

3. Brenner J, Rotenberg D, Jaakobi S, Stram Y, Guini-Rubinstein M, Menasherov S, et al. What can Akabane disease teach us about other arboviral diseases. Vet Ital. 2016;52:353-62. https://doi.org/10.12834/VetIt.547.2587.2

4. Hirashima Y, Kitahara S, Kato T, Shirafuji H, Tanaka S, Yanase T. Congenital malformations of calves infected with Shamonda virus, Southern Japan. Emerg Infect Dis. 2017;23:993-6. https:/ / doi.org/10.3201/eid2306.161946

5. Yanase T, Murota K, Hayama Y. Endemic and emerging arboviruses in domestic ruminants in East Asia. Front Vet Sci. 2020;7:168. https:// doi.org/10.3389/fvets.2020.00168

6. Steyn J, Motlou P, van Eeden C, Pretorius M, Stivaktas VI, Williams J, et al. Shuni virus in wildlife and nonequine domestic animals, South Africa. Emerg Infect Dis. 2020;26:1521-5. https://doi.org/10.3201/eid2607.190770

7. St George TD, Standfast HA. Simbu group viruses with teratogenic potential. In: Monath TP, editor. The arboviruses: epidemiology and ecology. Boca Raton (FL): CRC Press; 1989. p. 146-66.

8. Hoffmann B, Scheuch M, Höper D, Jungblut R, Holsteg M, Schirrmeier H, et al. Novel orthobunyavirus in cattle, Europe, 
2011. Emerg Infect Dis. 2012;18:469-72. https://doi.org/ 10.3201/eid1803.111905

9. Yanase T, Kato T, Aizawa M, Shuto Y, Shirafuji H, Yamakawa M, et al. Genetic reassortment between Sathuperi and Shamonda viruses of the genus Orthobunyavirus in nature: implications for their genetic relationship to Schmallenberg virus. Arch Virol. 2012;157:1611-6. https:/ / doi.org/10.1007/s00705-012-1341-8

10. Coupeau D, Bayrou C, Baillieux P, Marichal A, Lenaerts AC, Caty C, et al. Host-dependence of in vitro reassortment dynamics among the Sathuperi and Shamonda simbuviruses. Emerg Microbes Infect. 2019;8:381-95. https://doi.org/10.1080/22221751.2019.1586410

11. Golender N, Brenner J, Valdman M, Khinich Y, Bumbarov V, Panshin A, et al. Malformations caused by Shuni virus in ruminants, Israel, 2014-2015. Emerg Infect Dis. 2015;21:22678. https:/ / doi.org/10.3201/eid2112.150804

12. Brenner J, Yanase T, Kato T, Yaakobi S, Khinich E, Paz R, et al. Serological evidence suggests that several Simbu serogroup viruses circulated in Israel. Vet Ital. 2019;55:81-9.
13. Behar A, Rot A, Lavon Y, Izhaki O, Gur N, Brenner J. Seasonal and spatial variation in Culicoides community structure and their potential role in transmitting Simbu serogroup viruses in Israel. Transbound Emerg Dis. 2020;67:1222-30. https://doi.org/10.1111/tbed.13457

14. Behar A, Leibovich BB, Edery N, Yanase T, Brenner J. First genomic detection of Peaton virus in a calf with hydranencephaly in Israel. Vet Med Sci. 2019;5:87-92. https:/ / doi.org/10.1002/vms3.129

15. Kato T, Shirafuji H, Tanaka S, Sato M, Yamakawa M, Tsuda $\mathrm{T}$, et al. Bovine arboviruses in Culicoides biting midges and sentinel cattle in southern Japan from 2003 to 2013. Transbound Emerg Dis. 2016;63:e160-72. https://doi.org/10.1111/tbed.12324

Address for correspondence: Adi Behar, Department of Parasitology, Kimron Veterinary Institute, PO Box 12, Beit Dagan 50250, Israel; email: adib@moag.gov.il, adibehar@gmail.com.

\section{January 2021}

\section{Waterborne Infections}

- Impact of Human Papillomavirus Vaccination, Rwanda and Bhutan

- Aspergillosis Complicating Severe Coronavirus Disease

- Rising Ethnic Inequalities in Acute Rheumatic Fever and Rheumatic Heart Disease, New Zealand, 2000-2018

- Differential Yellow Fever Susceptibility in New World Nonhuman Primates, Comparison with Humans, and Implications for Surveillance

- Comparative Omics Analysis of Historic and Recent Isolates of Bordetella pertussis and Effects of Genome Rearrangements on Evolution

- Hospitalization for Invasive Pneumococcal Diseases in Young Children Before Use of 13-Valent Pneumococcal Conjugate

- Human Diversity of Killer Cell Immunoglobulin-Like Receptors and Human Leukocyte Antigen Class I Alleles and Ebola Virus Disease Outcomes

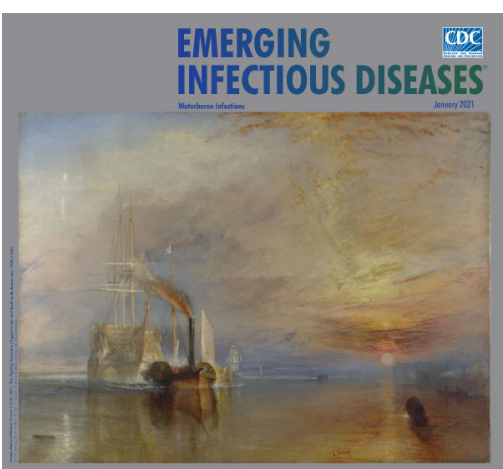

- IgG Seroconversion and Pathophysiology in Severe Acute Respiratory Syndrome Coronavirus 2 Infection

- Performance of Nucleic Acid Amplification Tests for Detection of Severe Acute Respiratory Syndrome Coronavirus 2 in Prospectively Pooled Specimens

- Susceptibility of Domestic Swine to Experimental Infection with Severe Acute Respiratory Syndrome Coronavirus 2

- Nosocomial Coronavirus Disease Outbreak Containment, Hanoi, Vietnam, March-April 2020
- Cellular Immunity in COVID-19 Convalescents with PCR-Confirmed Infection but with Undetectable SARS-CoV-2Specific IgG

- Estimating the Force of Infection for Dengue Virus Using Repeated Serosurveys, Ouagadougou, Burkina Faso

- Attribution of Illnesses Transmitted by Food and Water to Comprehensive Transmission Pathways Using Structured Expert Judgment, United States

- Intrafamilial Exposure to SARS-CoV-2 Associated with Cellular Immune Response without Seroconversion, France

- Invasive Fusariosis in Nonneutropenic Patients, Spain, 2000-2015

- Estimate of Burden and Direct Healthcare Cost of Infectious Waterborne Disease in the United States

- Territorywide Study of Early Coronavirus Disease Outbreak, Hong Kong, China

\section{EMERGING}

